\title{
THE INFLUENCE OF PARAMETERS OF HEAT TREATMENT ON THE MICROSTRUCTURE AND STRENGTH PROPERTIES OF THE ADI AND THE AVGI IRONS
}

\author{
${ }^{1 *}$ Aneta JAKUBUS, ${ }^{1 * *}$ Joanna KOSTRZEWA, ${ }^{2}$ Ewa OCIEPA \\ ${ }^{1}$ The Jacob of Paradies University in Gorzów Wielkopolski, Gorzów Wielkopolski, Poland, EU, \\ 1*iakubusaneta@wp.pl, ${ }^{1 *}$ ikostrzewa@ajp.edu.pl \\ ${ }^{2}$ Technical University of Czestochowa, Faculty of Production Engineering and Materials Technology, \\ Częstochowa, Poland, EU, ㄹe.ociepa@gmail.pl
}

https://doi.org/10.37904/metal.2021.4082

\begin{abstract}
The paper presents the results of investigation concerning the strength properties of the vermicular and the nodular cast iron both in the as-cast state and after the heat treatment held according to a couple of various options. The nodular cast iron exhibited almost $100 \%$ nodular graphite precipitates and the purely pearlitic matrix. The graphite precipitates in the vermicular cast iron were almost $100 \%$ vermicular ones, embedded in the pearlitic-ferritic matrix $(50 \% / 50 \%)$. The heat treatment of the examined cast iron types differed with respect to the temperature. The austenitization process was performed either at $900^{\circ} \mathrm{C}$ or at $960^{\circ} \mathrm{C}$, while austempering was held either at $290^{\circ} \mathrm{C}$ or at $390^{\circ} \mathrm{C}$. Both the austenitizing and the austempering time was constant and set to $90 \mathrm{~min}$. Both the as-cast specimens and the heat-treated ones were subjected to mechanical testing which allowed to determine their properties, namely $R m, R p 0,2, A 5$, and hardness. The change of the initial matrix to the ausferritic one resulted in the increase in mechanical properties, however the results were diversified depending on the type of graphite precipitates occurring in the material.
\end{abstract}

Keywords: Nodular cast iron, vermicular cast iron, austempering, AVGI, ADI

\section{INTRODUCTION}

The strength of the nodular cast iron can be enhanced by subjecting the material to austempering process. The proper selection of the heat treatment parameters allow to produce cast iron exhibiting distinctly higher strength and functional properties than the initial, thermally not treated material.

ADI (Austempered Ductile Iron) is a material well known to manufacturers, but there is an unceasing tendency to improve the material and to get the knowledge of mechanisms which allow to increase its properties.

Besides the nodular cast iron, also the vermicular one is an attractive material for the foundry industry. The properties of vermicular cast iron locate this material between the grey and the nodular cast iron types [1]. Admittedly, the alloy is characterised by lower mechanical properties than the nodular cast iron (although it surpasses the grey iron with flake graphite in this respect), but it has in turn distinctly greater heat conductivity and damping capacity than the cast iron with nodular graphite. This leads to the great interest in this material, especially from the automotive industry [2]. An exemplary application can be the 3.0 TDI engine block (produced by Audi Company) made of vermicular cast iron [3]. It can be mentioned that the grey cast iron formerly commonly used for engine hulls is less rigid and exhibits lower fatigue resistance than the vermicular cast iron. Therefore the use of vermicular cast iron allows to reduce the wall thickness of castings, by the same reducing the mass of the entire individual casting even by about $20 \%$ [4]. 
The advantageous properties, which the nodular cast iron gained due to the austempering process transforming it into the ADI, were the reason for applying the same type of heat treatment to the vermicular cast iron.

\section{AUTHOR'S INVESTIGATIONS}

The nodular and the vermicular cast iron produced by one of the domestic foundries was used for the purpose of investigation. Test coupons of the Ilb type were produced (in accordance with [5]). The test part of the mentioned test coupons was the material of which the tensile specimens were cut out. After measuring the strength properties, the specimens intended for metallographic examination were cut out of the end tabs of the tensile specimens.

Chemical compositions of the examined cast iron types, both nodular and vermicular, are presented in Table 1.

Table 1 Chemical composition of the nodular and the vermicular cast iron

\begin{tabular}{|c|c|c|c|c|c|c|c|}
\hline \multicolumn{7}{|c|}{ Chemical composition (\%) } & \multirow{2}{*}{$\mathrm{Sc}^{*}$} \\
\hline $\mathrm{C}$ & $\mathrm{Si}$ & $\mathrm{Mn}$ & $\mathrm{Cu}$ & $\mathrm{P}$ & S & $\mathrm{Mg}$ & \\
\hline \multicolumn{8}{|c|}{ Nodular cast iron } \\
\hline 3.57 & 2.33 & 0.38 & 0.55 & 0.061 & 0.008 & 0.062 & 0.9 \\
\hline \multicolumn{8}{|c|}{ Vermicular cast iron } \\
\hline 3.22 & 2.38 & 0.192 & 1.02 & 0.054 & 0.022 & 0.027 & 0.9 \\
\hline
\end{tabular}

The metallographic examinations were performed by the methods of optical microscopy, using the Nikon Eclipson optical microscope. Classification of graphite precipitates was performed for the non-etched specimens according to the Standard [6]. The microstructures were assessed in accordance with the Standard [7]. Table 2 juxtaposes the results of examinations for the as-cast material of both examined types.

Table 2 Quantities of pearlite and ferrite along with graphite characteristics in the examined cast iron

\begin{tabular}{|c|c|c|}
\hline Cast iron type & Assessment of graphite precipitates [6] & $\begin{array}{c}\text { Microsection area occupied by pearlite and ferrite } \\
\text { [7] }\end{array}$ \\
\hline \multirow{2}{*}{ Nodular } & $95 \%$ VI $4 / 5+$ & $\mathrm{P} 95$ \\
Vermicular & $5 \%$ V 4/5 & Fe05 \\
\hline & $95 \%$ III 4/5+ & P50 \\
\hline
\end{tabular}




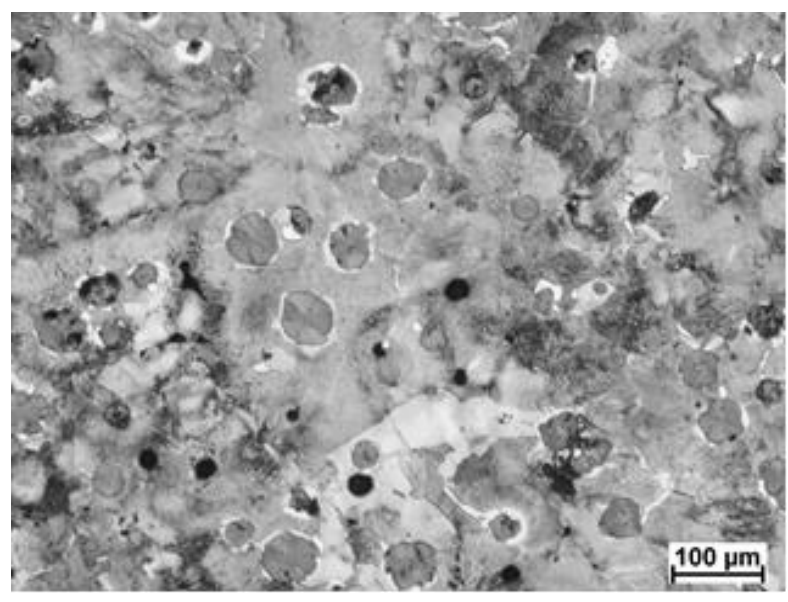

Figure 1 Microstructure of the nodular cast iron etched with Nital, magn. 100x

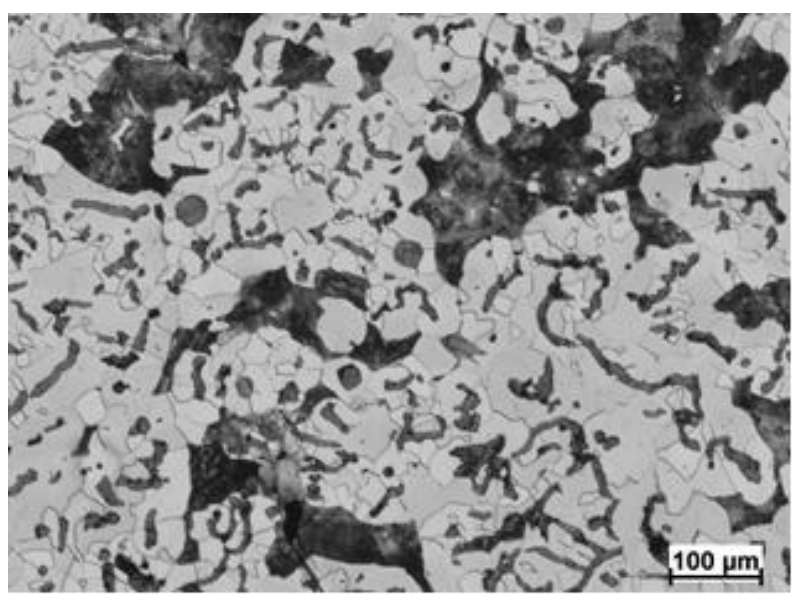

Figure 2 Microstructure of the vermicular cast iron etched with Nital, magn. 100x

Microstructures of the examined alloys are presented in Figures 1 and 2.

The data given in Table 2, as well as Figures 1 and 2, indicate that the examined vermicular cast iron contained over $95 \%$ of vermicular graphite precipitates, and about $5 \%$ of nodular graphite. The alloy exhibited the pearlitic-ferritic matrix, as was initially assumed, and the contribution of each of these phases was equal to approximately $50 \%$. The nodular cast iron contained mainly nodular graphite (95\%), and the matrix was pearlitic.

The examined cast iron types were subjected to the thermal treatment consisting in austempering. Taking up the suggestion resulting from initial examinations and the thermal treatment reported by some authors with respect either to the nodular cast iron [8-11] or to the vermicular one [12], it was assumed that the austenitization would be held at the temperature equal to either $900^{\circ} \mathrm{C}$ or $960^{\circ} \mathrm{C}$, and the quenching at the temperature of either $290^{\circ} \mathrm{C}$ or $390^{\circ} \mathrm{C}$. The difference in the latter temperature values equal to $100^{\circ} \mathrm{C}$ was applied in order to achieve structures with greater or lesser fractions of ferrite and austenite. The alternative sets of parameters applied during the heat treatment, denoted as 1 to 4 , are presented in Table 3 . Both the austenitization time and the austempering time were constant and equal to $90 \mathrm{~min}$.

The tensile specimens were cut out of the test part of the cast coupons of the llb type. The specimens intended for the further heat treatment had intentionally increased their initial thicknesses to compensate the possible scaling during the austenitization process. This allowance was removed after the heat treatment. 
The heat treatment was performed at the research stand situated at Odlewnie Polskie S.A. enterprise in Starachowice. Austenitization was held in an air atmosphere using the resistance chamber furnace made by 'ELTERMA' Company. Austempering was performed in a quenching tank, in a salt bath used as the quenching agent. After taking the specimens out of the tank, the salt residues were washed off.

Table 3 Parameters of heat treatment applied to the cast iron

\begin{tabular}{|c|c|c|}
\hline $\begin{array}{c}\text { Designation of heat treatment } \\
\text { option }\end{array}$ & $\begin{array}{c}\text { Temperature of austenitization } \\
\mathrm{T}_{\mathrm{Y}}\left({ }^{\circ} \mathrm{C}\right)\end{array}$ & $\begin{array}{c}\text { Temperature of austempering } \\
\mathrm{T}_{\mathrm{pi}}\left({ }^{\circ} \mathrm{C}\right)\end{array}$ \\
\hline Option 1 & 960 & 390 \\
\hline Option 2 & 960 & 290 \\
\hline Option 3 & 900 & 390 \\
\hline Option 4 & 900 & 290 \\
\hline
\end{tabular}

Figure 3 presents the microstructure of the examined alloys after the heat treatment according to the four specified options.

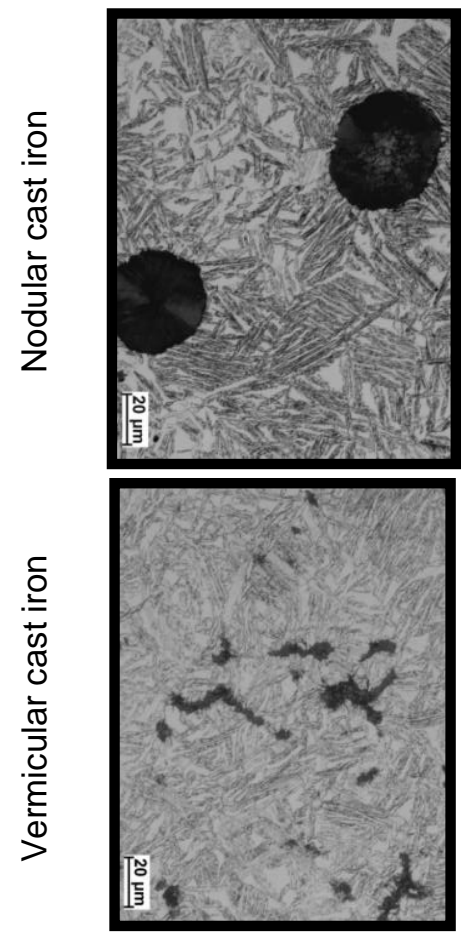

a)
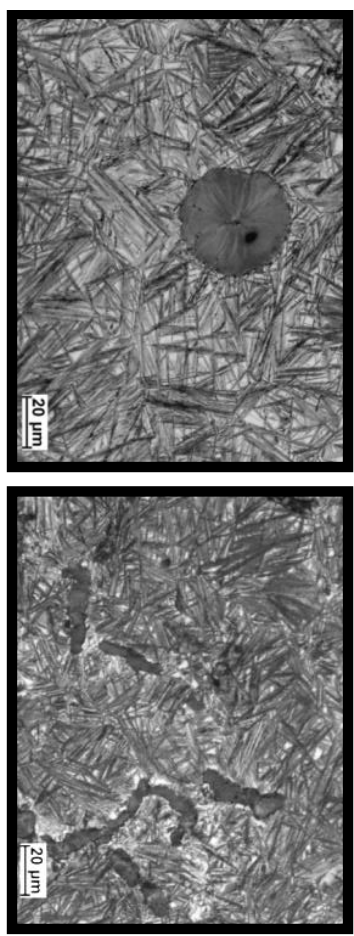

b)
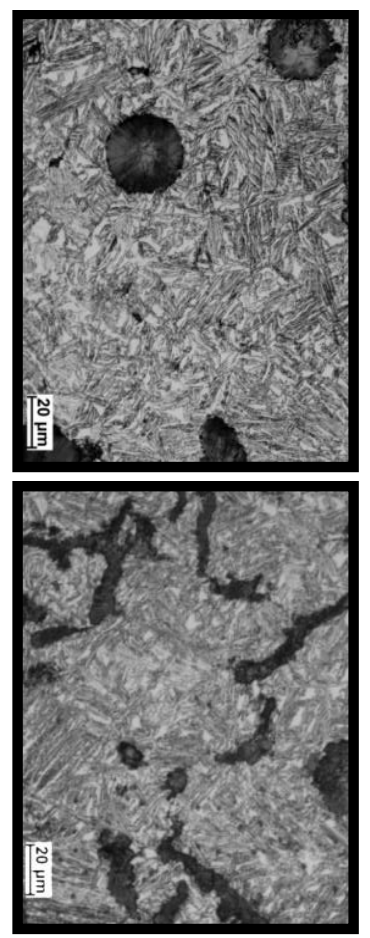

c)
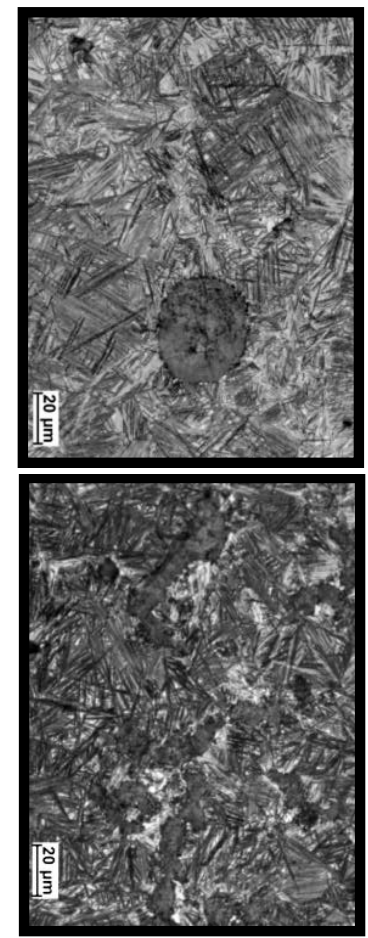

d)

Figure 3 Microstructures of nodular and vermicular cast iron after the heat treatment according to the option:

a) No. $1\left(\mathrm{~T}_{\gamma}=960^{\circ} \mathrm{C}, \mathrm{Tpi}^{\circ} 390^{\circ} \mathrm{C}\right)$; b) No. $2\left(\mathrm{~T} \gamma=960^{\circ} \mathrm{C}, \mathrm{Tp} i=290^{\circ} \mathrm{C}\right)$; c) No. $3\left(\mathrm{~T}_{\gamma}=900^{\circ} \mathrm{C}, \mathrm{Tp}=390^{\circ} \mathrm{C}\right)$; d) No. $4\left(\mathrm{~T} \gamma=900^{\circ} \mathrm{C}, \mathrm{Tpi}=290^{\circ} \mathrm{C}\right)$

The strength properties were examined by means of the ZWICK 1488 tester. Hardness of the materials was checked by means of the Brinell hardness tester with a ball of $2.5 \mathrm{~mm}$ diameter under the load of 1,839 $\mathrm{N}$. Tables 4 and $\mathbf{5}$ give the average values of Rm, R0.2, A5, and the hardness of both the nodular and the vermicular cast iron, both in the as-cast state and after the heat treatment. For each type of the examined cast iron and for each option of the heat treatment as well as for the as-cast state, the average values of Rm, R0.2, A5, were calculated from measurements taken from four specimens. As to the average hardness, its values 
were calculated from twelve measurements carried out for each cast iron type in every state (i.e. for the ascast specimens and the heat-treated specimens of every option).

Table 4 Average values of the tensile strength $\mathrm{Rm}$, yield strength $\mathrm{R} 0.2$, elongation $\mathrm{A} 5$, and the hardness of the nodular cast iron before and after the heat treatment

\begin{tabular}{|c|c|c|c|c|c|}
\hline \multirow{2}{*}{\multicolumn{2}{|c|}{ State of the examined cast iron }} & \multicolumn{4}{|c|}{ Strength properties } \\
\hline & & $\mathrm{R}_{\mathrm{m}}(\mathrm{MPa})$ & $\mathrm{R}_{\mathrm{p} 0.2}(\mathrm{MPa})$ & $A_{5}(\%)$ & $\mathrm{HB}$ \\
\hline \multicolumn{2}{|l|}{ As-cast } & 590 & 424 & 2.2 & 255 \\
\hline \multirow{4}{*}{$\begin{array}{l}\text { Heat-treated according to } \\
\text { option* }^{*}\end{array}$} & 1 & 829 & 583 & 4.4 & 283 \\
\hline & 2 & 1,346 & 920 & 1.5 & 407 \\
\hline & 3 & 979 & 592 & 6.5 & 299 \\
\hline & 4 & 1,539 & 953 & 2.2 & 436 \\
\hline
\end{tabular}

Table 5 Average values of the tensile strength $\mathrm{Rm}$, yield strength $\mathrm{R} 0.2$, elongation $\mathrm{A} 5$, and the hardness of the vermicular cast iron before and after the heat treatment

\begin{tabular}{|c|c|c|c|c|}
\hline \multirow{2}{*}{ State of the examined cast iron } & \multicolumn{4}{|c|}{ Strength properties } \\
\hline & $\mathrm{R}_{\mathrm{m}}(\mathrm{MPa})$ & $\mathrm{R}_{\mathrm{p} 0.2(\mathrm{MPa})}$ & $A_{5}(\%)$ & $\mathrm{HB}$ \\
\hline As-cast & 371 & 331 & 2.1 & 183 \\
\hline \multirow{4}{*}{$\begin{array}{l}\text { Heat-treated according to } \\
\text { option* }^{*}\end{array}$} & 623 & 485 & 1.6 & 260 \\
\hline & 824 & 584 & 0.7 & 334 \\
\hline & 616 & 492 & 1.0 & 280 \\
\hline & 954 & 808 & 0.4 & 352 \\
\hline
\end{tabular}

\section{CONCLUSION}

The paper is focused on the mechanical properties of the ADI and AVGI cast irons, particularly on the dependence between their properties and the temperature of both the austenitization and the austempering processes. The work discusses two variable parameters of heat treatment, namely the austenitization temperature, which was set to be either $900^{\circ} \mathrm{C}$ or $960^{\circ} \mathrm{C}$, and the austempering temperature, which was selected as either $290^{\circ} \mathrm{C}$ or $390^{\circ} \mathrm{C}$, so that four options of thermal treatment were eventually considered (see Table 3).

It results from the observation of microstructures shown in Figure 3 that both the nodular and the vermicular cast iron types subjected to the heat treatment are characterised by the ausferritic matrix, consisting of the acicular ferrite and austenite supersaturated with carbon. It can be seen that the area fraction occupied by individual phases depends on the temperature of austempering. The matrix was analysed by a computer program in order to find the fraction of the residual austenite. The results indicated that the largest fraction of the residual austenite in the matrix occurred in specimens austempered at $390^{\circ} \mathrm{C}$ (treatment options 1 and 3 ). The specimens austempered at $290^{\circ} \mathrm{C}$ (treatment options 2 and 4) were characterised by lower fraction of the residual austenite.

The data gathered in Tables $\mathbf{4}$ and $\mathbf{5}$ prove that the highest tensile strength and yield strength values occurred for both the nodular and the vermicular cast iron thermally treated according to the options 2 or 4 . The lower temperature of austempering $\left(290^{\circ} \mathrm{C}\right)$ resulted in the increased tensile strength and yield strength. The highest values of Rm and R0.2 for vermicular cast iron (954 MPA and $808 \mathrm{MPa}$, respectively) and for nodular cast iron 
(1,539 MPa and $953 \mathrm{MPa}$, respectively) were achieved after the heat treatment held in accordance with the option 4. It should be noticed that the austenitization temperature influenced the values of $\mathrm{Rm}$ and R0.2. The higher austenitization temperature $\left(960^{\circ}\right.$ for the examined case) resulted in the tensile strength reduced by about $13 \%$.

An increase in the temperature of austempering from $290^{\circ} \mathrm{C}$ to $390^{\circ} \mathrm{C}$ lead to the distinct increase of elongation.

The differences in mechanical properties of cast iron types thermally treated according to various options were related to different percentage of ferrite and austenite occurring in the matrices of examined materials. There was observed a tendency towards the increased ferrite fraction in the matrix, and by the same the reduced austenite fraction, for the increased austempering temperature. The greater ferrite content in the matrix resulted in an increase in plastic properties of the cast iron due to ferrite plasticity, at the cost of decreased tensile strength.

Considering the hardness of the examined as-cast vermicular cast iron, it can be stated that it was lower than the hardness of the nodular cast iron. This is related to the respectively large ferrite percentage in the matrix, which amounted to $50 \%$. The hardness of the examined materials after the heat treatment depended on the applied parameters of the treatment, particularly on the austempering temperature Tpi. The higher the Tpi temperature, the lower was the resulting hardness of the examined cast iron.

\section{REFERENCES}

[1] Sorelmetal: About nodular cast iron. Warsaw: Metals \& Minerals Ltd., 2006.

[2] KACZOROWSKI, M. The structure and mechanical properties of the isothermally quenched cast iron with mixed graphite. Archives of Foundry. 2002, vol. 2, issue 6, pp. 127-134.

[3] We check the popular motors 2.7 and 3.0 TDI. Auto Świat. Second-hand. 29th of June 2015, pp. 44-45.

[4] Collective work edited by PYTEL, A. Innovative cast materials resistant to thermal fatigue. Part 1. General issues. Cracow: Foundry Research Institute, 2012, pp. 32-42.

[5] Polish Standard PN-EN 1563, Founding. Spheroidal graphite cast irons. February, 2000.

[6] Polish Standard PN-EN ISO 945-1. Microstructure of cast irons - Part 1: Graphite classification by visual analysis. November, 2009. Amendment: PN $\square$ EN ISO 945-1:2009/AC. April, 2010.

[7] Polish Standard PN 75/H-04661. Grey cast iron, nodular cast iron and malleable. Metallographic examinations. Determining of microstructure.

[8] PODRZUCKI, C. Cast iron. Structure, properties, applications. Cracow: ZG Stop, 1991.

[9] FURMANK. J., BINCZYK, F., GRADOŃ, P. Effect of post-weld treatment parameters on the microstructure of ADI cast iron. Transactions of the Institute for Ferrous Metallurgy. 2010, vol. 4, pp. 5-14.

[10] BOROWSKI, A.W. Synthetic austempered nodular cast iron (ADI). XXIII Scientific and Technical Symposium of the Foundry Division of the Institute of Materials Engineering. Warsaw University of Technology, 1998, p. 2.

[11] WRÓBEL, J. Thermal fatigue resistance of the ADI cast iron. Doctoral thesis. AGH University of Science and Technology, Cracow, 2013.

[12] MIERZWA, P. The effect of thermal treatment on the selected properties of cast iron with vermicular graphite. Doctoral thesis. Czestochowa University of Technology, 2010. 